\title{
ESTABILIDADE OPERACIONAL POR MEIO DE "BUFFER TANK" INTERMEDIÁRIO*
}

Samuel Vasconcellos ${ }^{1}$

\section{Resumo}

Em plantas de separação do tipo PSA ocorrem oscilações na vazão de ar intrínsecas a este processo, devido à repressurização dos vasos pré-purificadores ser feita em intervalos muito curtos. Por meio da instalação de um buffer tank foi possível tornar a coluna de destilação mais estável, aumentando a produção de líquidos, reduzindo a demanda de energia e otimizando a pré-purificação.

Palavras-chave: Buffer tank; PSA.

\section{OPERATIONAL STABILITY IMPROVEMENT DUE TO A PROCESS BUFFER TANK INSTALLATION}

\section{Abstract}

Air flow oscillations are normal in PSA type plants, in which the Pre-purification beds repressurization steps occur in a significant frequency. The installation of an Air Buffer tank allowed to increase air flow up to the maximum compressor capacity, better stabilizing the distillation column, improving purification capacity and at the end increasing Bulk production.

Keywords: Buffer tank; PSA.

1 Engenheiro Elétrico, Gerente de Produtividade, Produtividade, Centro Universitário Salesiano de São Paulo, Americana, SP, Brasil.

* Contribuição técnica ao $35^{\circ}$ Seminário de Balanços Energéticos Globais e Utilidades e $29^{\circ}$ Encontro de Produtores e Consumidores de Gases Industriais, 13 a 15 de agosto de 2014, São Paulo, SP, Brasil. 


\section{INTRODUÇÃO}

Uma unidade de separação de ar pode ser dividida em quatro etapas principais: compressão do ar; pré-refrigeração; purificação; colb box, que consiste no conjunto de colunas, trocadores de calor e turbinas. No geral, o sistema de purificação pode ser do tipo TSA (temperature swing adsorption), onde o ciclo de operação é algo em torno de seis horas, ou tipo PSA (pressure swing adsorption), onde os ciclos de operação são de aproximadamente quinze minutos.

O sistema de regeneração destes vasos no caso do vaso PSA, funciona em etapas sequenciais: primeiro há uma despressurização, em seguida passa-se uma corrente de purga que retira as impurezas e em seguida o vaso deve ser repressurizado. Nesta última etapa, parte do ar que seria direcionado para o processo, é utilizado para elevar a pressão de um dos vasos, causando um distúrbio na vazão que segue para a próxima etapa.

No caso da purificação feita através do sistema PSA, devido ao seu ciclo relativamente pequeno, os distúrbios causados no processo afetam a operação da unidade regularmente. Portanto vem sendo estudados com grande intensidade projetos de melhoria que visam reduzir esse impacto.

O buffer tank consiste em um vaso, o qual durante todo o ciclo de operação do vaso, armazena gradativamente uma parcela do ar que seguiria para o processo, de modo a não causar distúrbios no mesmo. Todavia, durante a etapa de repressurização essa quantidade de ar retido é devolvida ao processo num curto espaço de tempo, a fim de amenizar as oscilações inerentes ao sistema de purificação PSA. Os compressores de ar são dimensionados com capacidade acima da média, para suportar esses momentos de repressurização. Entretanto mesmo quando bem ajustados seus controles, estes têm um tempo de resposta que ainda causa tais distúrbios.

Neste processo, uma variável crítica é a capacidade de reter o dióxido de carbono contido no ar, para que este não siga para o processo, por se um parâmetro de segurança que é controlado dentro de valores pré-estabelecidos.

\section{MATERIAIS E MÉTODOS}

O processo de compressão e purificação do ar está representado na figura a seguir. No projeto em questão, o ciclo dos vasos é de vinte minutos, isto é, a cada vinte minutos o compressor de ar tinha que aumentar a potência para que o incremento de vazão fosse suficiente a fim de suprir o ar demandado pela repressurização.

* Contribuição técnica ao $35^{\circ}$ Seminário de Balanços Energéticos Globais e Utilidades e $29^{\circ}$ Encontro de Produtores e Consumidores de Gases Industriais, 13 a 15 de agosto de 2014, São Paulo, SP, Brasil. 


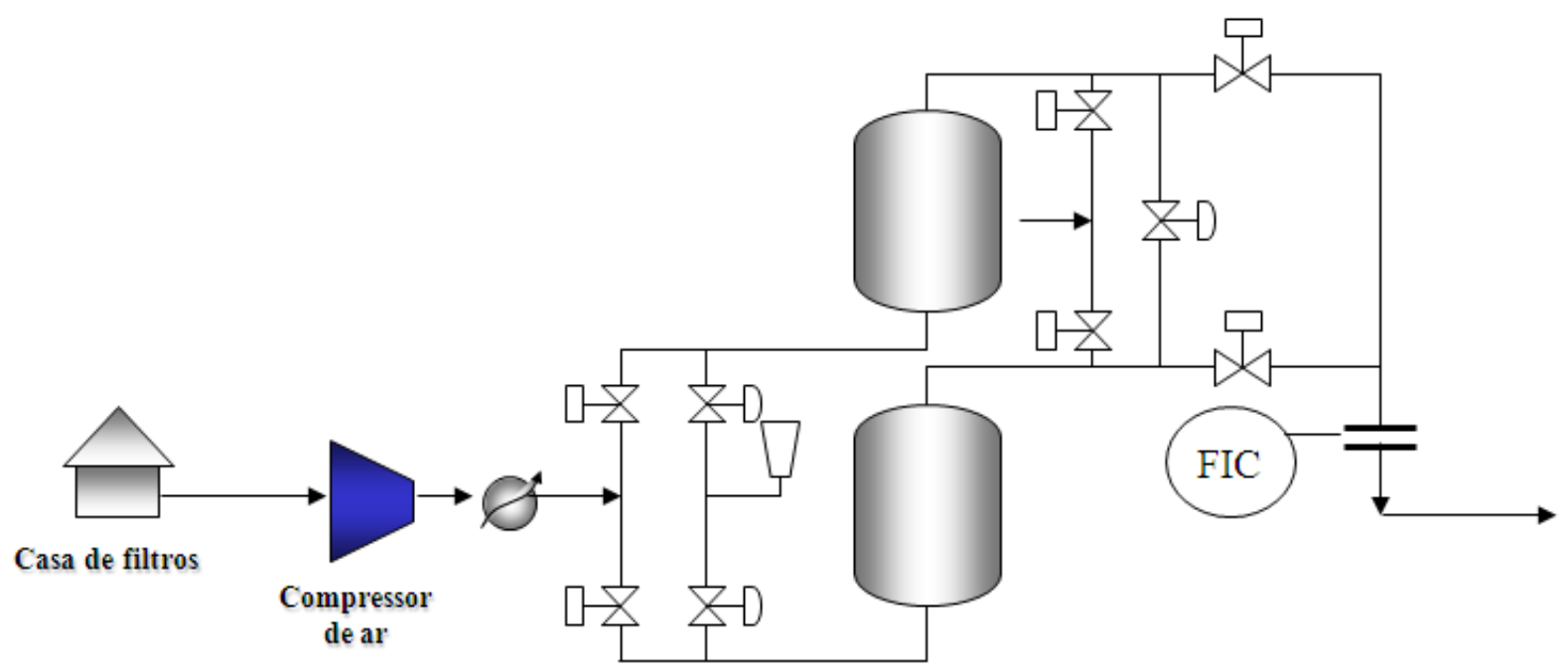

Figura 1: Antes da instalação do Buffer

O Buffer tank foi instalado depois do sistema de pré purificação, assim como demonstrado na figura 2.

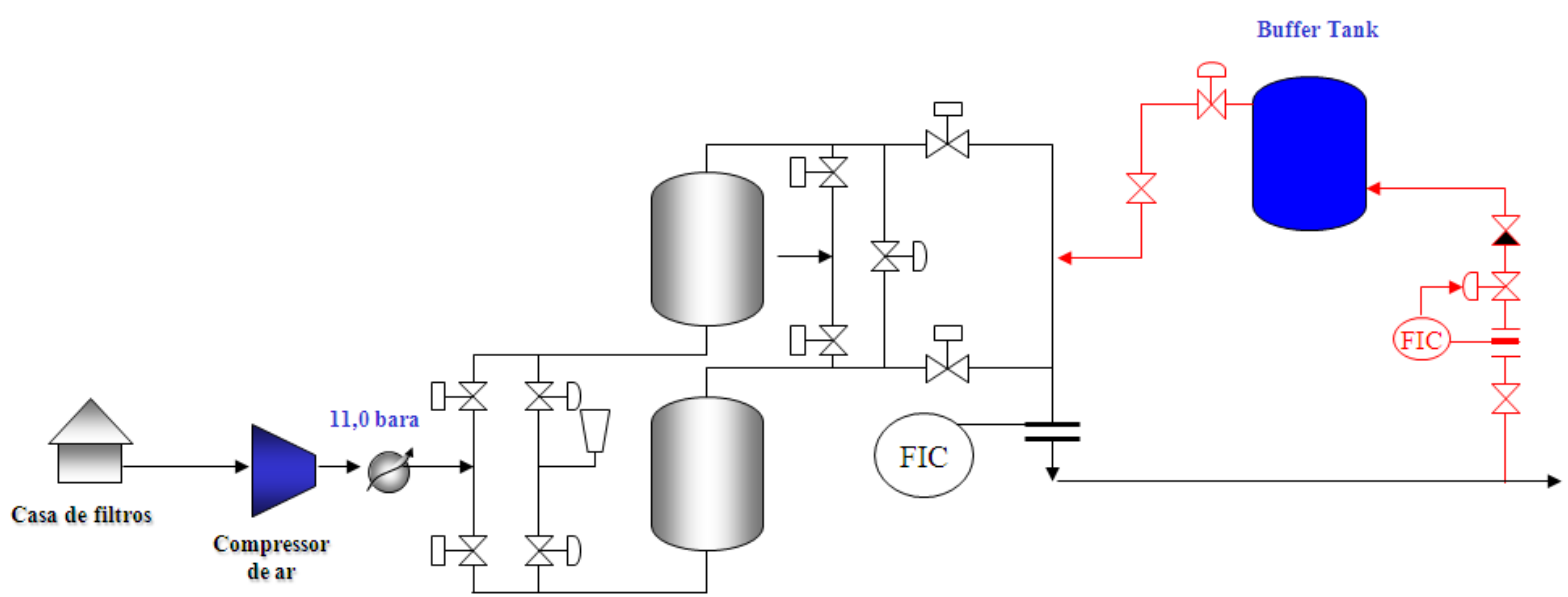

Figura 2: Após a instalação do Buffer

A má performance das torres estava impedindo o resfriamento adequado do ar no pós resfriador do compressor de ar. Esta etapa precede a etapa de limpeza do ar nos vasos pré purificadores, reduzindo a capacidade dos vasos processarem o ar. A quantidade de dióxido de carbono que segue para o processo já estava no limite operacional, restringindo a capacidade de produção da planta. A operação do Buffer tank trouxe um inesperado resultado no que tange a otimização da purificação.

A foto da Figura 3 mostra o vaso "Buffer Tank" já operacional, em etapa final de acabamento.

* Contribuição técnica ao $35^{\circ}$ Seminário de Balanços Energéticos Globais e Utilidades e $29^{\circ}$ Encontro de Produtores e Consumidores de Gases Industriais, 13 a 15 de agosto de 2014, São Paulo, SP, Brasil. 

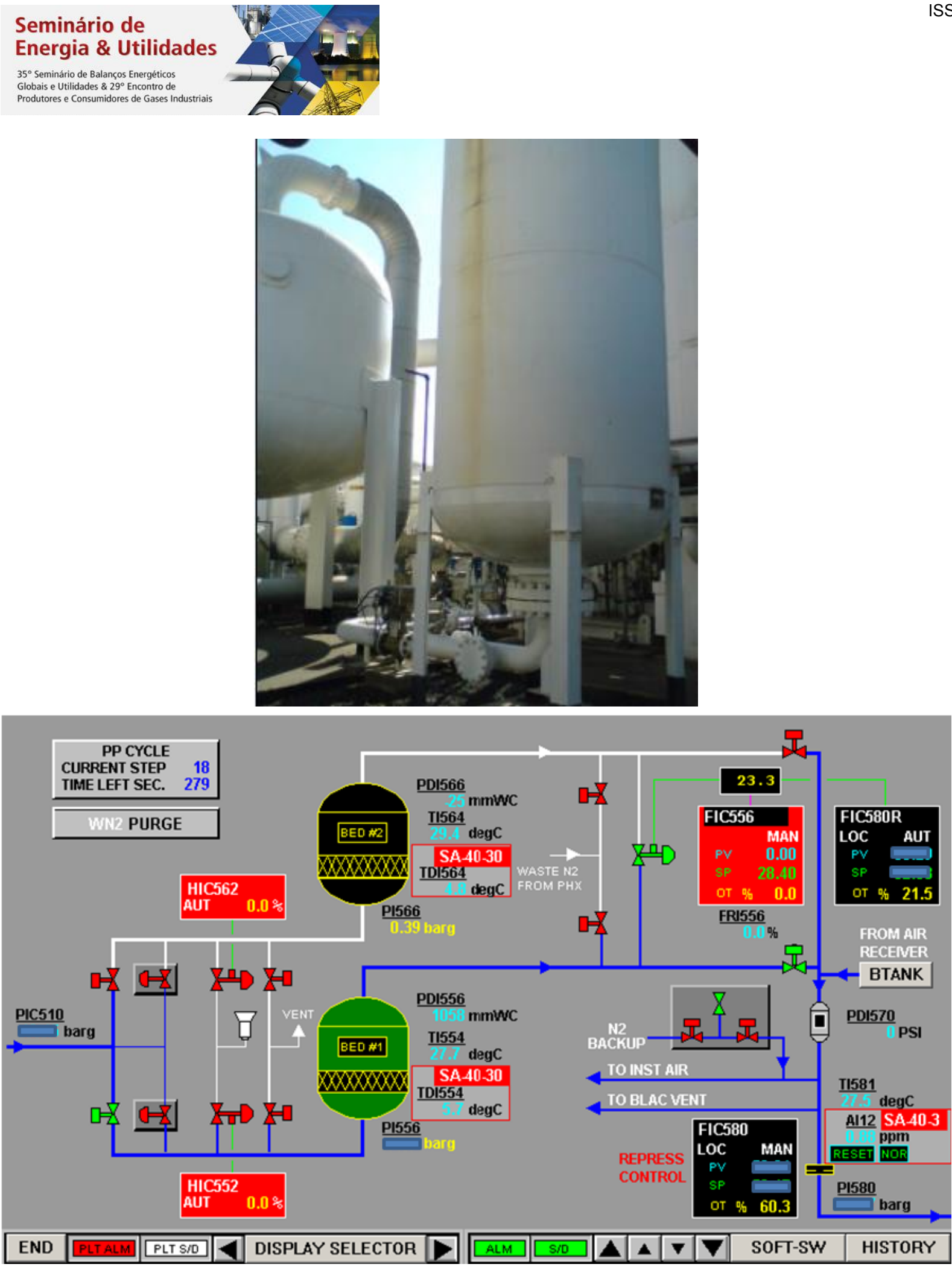

Figura 3: Tela do sistema de controle da planta com o Buffer em operação.

\section{RESULTADOS E DISCUSSÃO}

A quantidade de dióxido de carbono que segue para o processo já estava no limite operacional, a qual por ser diretamente proporcional, impedia o aumento de ar que poderia ser enviado para a planta. Após a modificação, com redução nas oscilações de ar do processo, foi possível observar que a quantidade de dióxido de carbono na saída dos purificadores também diminuiu (Figura 4).

* Contribuição técnica ao $35^{\circ}$ Seminário de Balanços Energéticos Globais e Utilidades e $29^{\circ}$ Encontro de Produtores e Consumidores de Gases Industriais, 13 a 15 de agosto de 2014, São Paulo, SP, Brasil. 


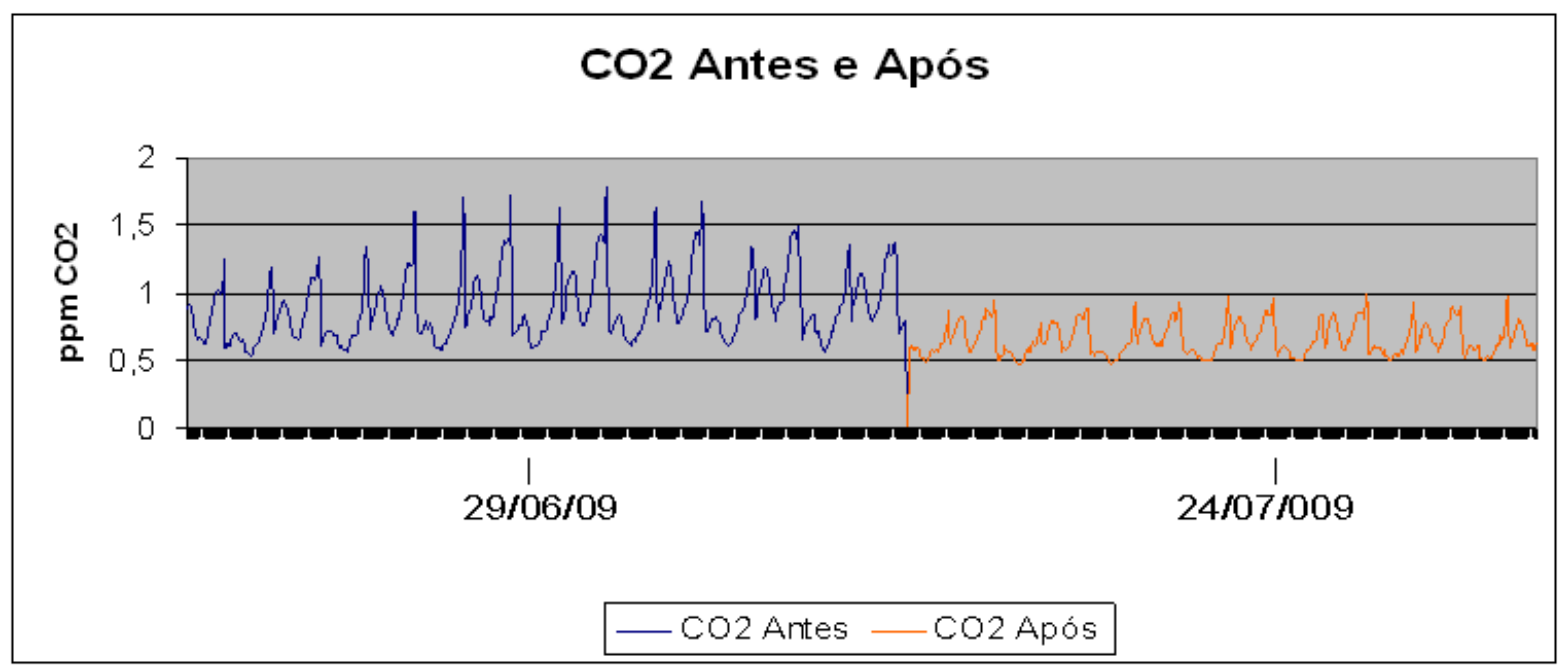

Figura 4: Análise de dióxido de carbono

Com a redução na quantidade de dióxido de carbono, foi possível um aumento na vazão de ar para planta, realizando assim um incremento na produção (Figura 5).

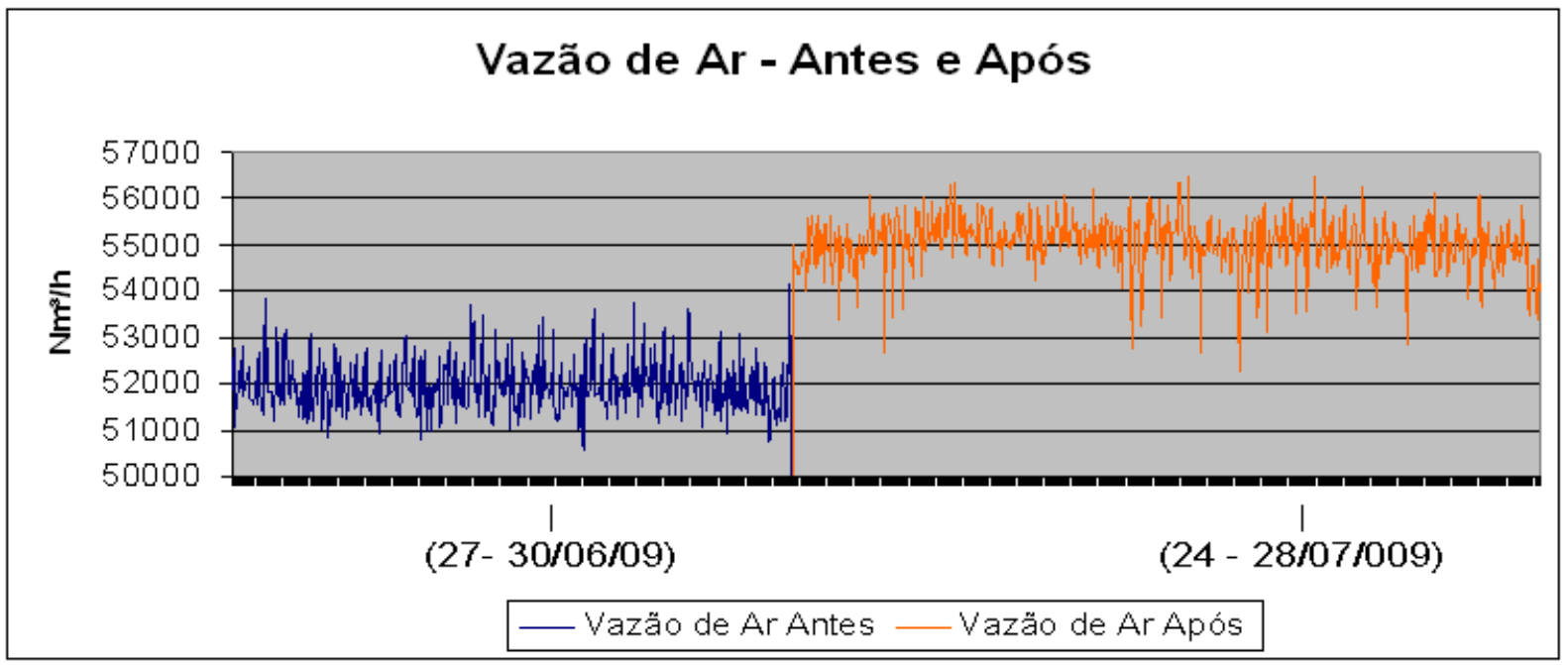

Figura 5: Incremento na vazão de ar

Com a instalação do buffer tank, o aumento na vazão de ar cada etapa de repressurização dos ciclos de purificação pode ter a sua magnitude reduzida, gerando menores picos consumo energético, assim como representado na Figura 6.

* Contribuição técnica ao $35^{\circ}$ Seminário de Balanços Energéticos Globais e Utilidades e $29^{\circ}$ Encontro de Produtores e Consumidores de Gases Industriais, 13 a 15 de agosto de 2014, São Paulo, SP, Brasil. 

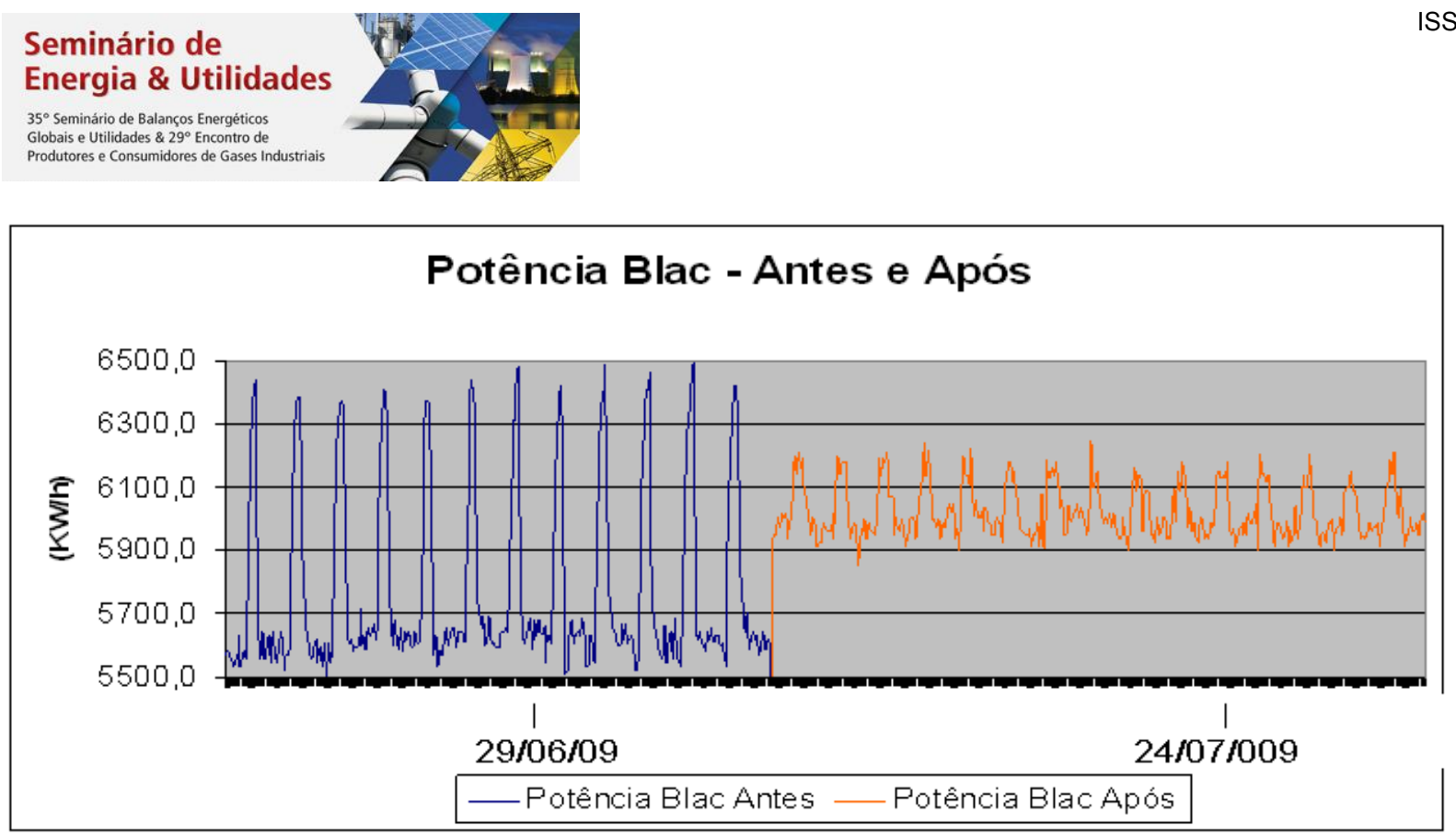

Figura 6: Redução de potência

A redução das oscilações geradas no processo, pela instalação do buffer tank, resulta em uma maior estabilidade das temperaturas da coluna de destilação, e consequente maior produção da unidade. A estabilidade pode ser representada pela quantidade de oxigênio na retirada da corrente rica em argônio para a coluna, representada pela Figura 7 .

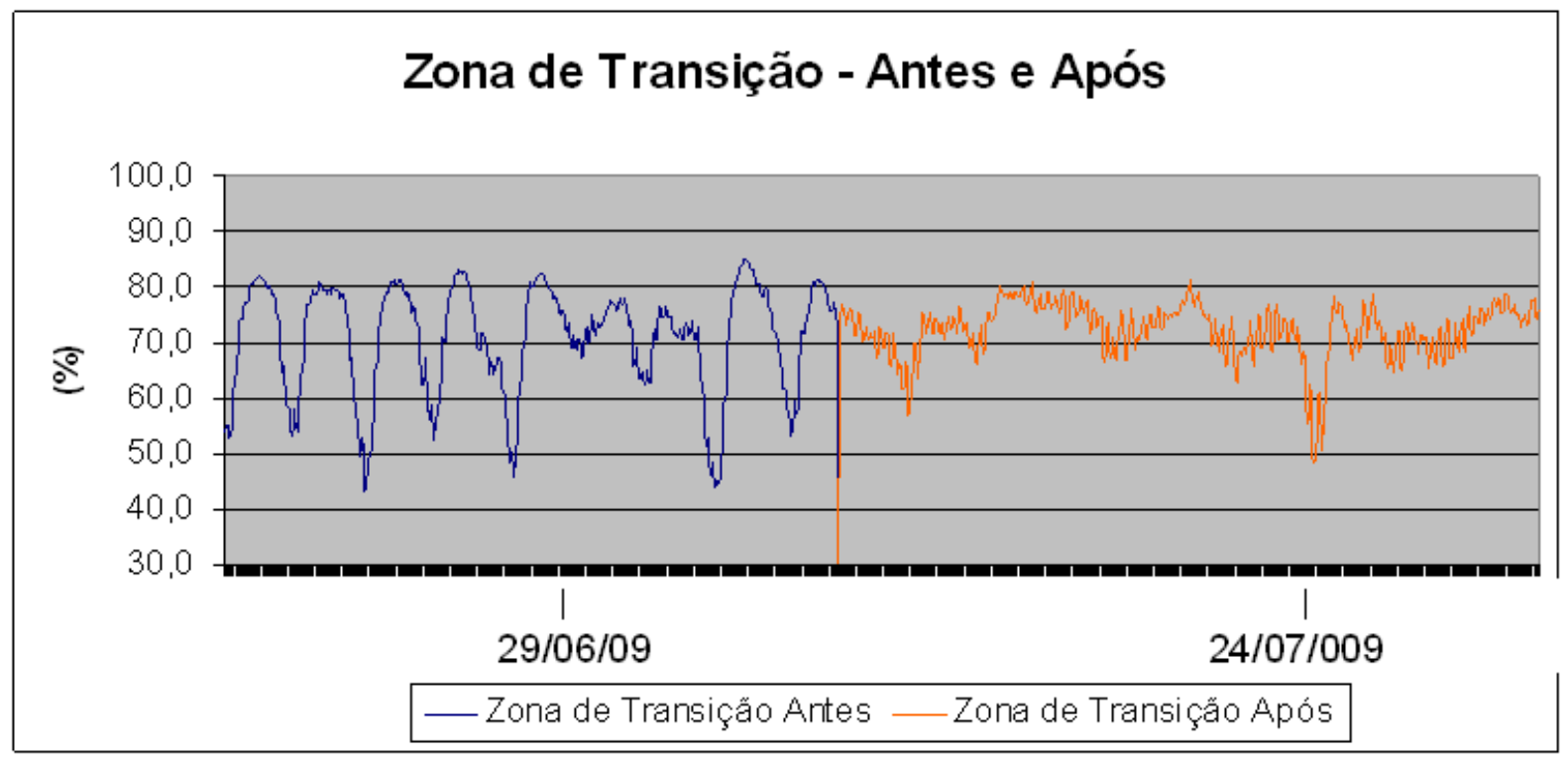

Figura 7: Estabilização da Planta

\section{CONCLUSÃo}

A instalação do buffer tank permitiu a estabilidade esperada e explorar os limites dos equipamentos. Os resultados medidos foram:

- aumento da vazão de ar em 4,3\%

- aumento da produção de 02 gasoso em 3,3 \%

- aumento da produção de Argonio em 3,2\%

- redução da demanda de energia em 200 kW.

* Contribuição técnica ao $35^{\circ}$ Seminário de Balanços Energéticos Globais e Utilidades e $29^{\circ}$ Encontro de Produtores e Consumidores de Gases Industriais, 13 a 15 de agosto de 2014, São Paulo, SP, Brasil. 
Este projeto apresentou um Pay Back simples inferior a 1 ano e vem sendo replicado em unidades similares (com sistemas de purificação tipo PSA) onde haja necessidade de aumento de produção.

\section{Agradecimentos}

Agradecemos em especial aos Srs Valter Martins (Supervisor de Produção) e Antonio Jose (Gerente da Unidade) pelo incentivo, suporte local e criação das condições de execução necessárias.

\section{FONTES}

1 ASME Section VIII, Division 2 - Rules for Construction of Pressure Vessels.

2 UNISIM Process Modeling Software. 